\title{
AVALIAÇÃO DO EFEITO DA APLICAÇÃO TÓPICA DO ÁCIDO GLUTÂMICO NA PELE
}

\author{
Beatriz de Andrade Berti \\ Graduanda de Enfermagem pela Universidade Estadual de Campinas \\ beaandradeb@gmail.com
}

INTRODUÇÃO: O Ácido Glutâmico é o principal neurotransmissor excitatório em neurônios. Efeitos prejudiciais, seja aumentando ou diminuindo sua atividade, resultam na manifestação de patologias neuropsiquiátricas, como a esquizofrenia e doença de Alzheimer. Interessantemente, compartilhando a mesma origem embrionária, queratinócitos, também expressar receptores para ácido glutâmico, assim como seus transportadores. Distribuições anormais do receptor de ácido glutâmico têm sido mostradas em modelos hiperproliferativos como psoríase e regeneração de pele. No entanto, a função biológica do ácido glutâmico neste tecido não tem sido descrita. OBJETIVO: Identificar os efeitos do ácido glutâmico tópico na pele. MÉTODO: Estudo experimental com camundongos Swiss machos com 08 semanas de idade, provenientes do Centro de Bioterismo da UNICAMP e mantidos em caixas individuais, com ração padrão para roedores e água "ad libitum" e sob condição padronizada de iluminação e temperatura de $22 \pm 2^{\circ} \mathrm{C}$ serão divididos em cinco grupos com $n$ de 5 e tratados topicamente com ácido glutâmico em diferentes concentrações. RESULTADOS: O Ácido glutâmico regula a expressão e plasticidade genes marcadores de macrófagos na pele. A aplicação tópica do Ácido glutâmico na pele diminuiu significativamente a expressão do gene $\mathrm{F} 4 / 80$, gene expresso em macrófagos, em todas as concentrações testadas. Especificamente, a aplicação tópica de Ácido Glutâmico 1\% diminuiu significativamente a expressão do gene Arginase 1, sendo este relacionado ao fenótipo pró-inflamatório dos macrófagos M1. No entanto, a aplicação tópica de Ácido Glutâmico não modulou os gene CD11b, MCP1 e CD36. Ácido glutâmico modula proliferação e diferenciação de células epiteliais. $\mathrm{Na}$ avaliação microscópica, observamos aumento na espessura da com aumento da camada córnea e maior descamação. Este aumento é diretamente proporcional com a concentração de Ácido Glutâmico aplicado na pele integra. Especificamente, na aplicação do Ácido Glutâmico 10\%, observamos uma distribuição aberrante dos queratinócitos, com uma camada basal difusa e núcleos na camada córnea. CONCLUSÃO: Nosso 
trabalho identificou os efeitos da aplicação tópica de Ácido Glutâmico na pele íntegra. Desse modo, observamos que o tratamento regula a expressão e plasticidade genes marcadores de macrófagos na pele. Além disso, identificamos os efeitos micro e macro morfológicos da pele como também a identificação da expressão de proteínas envolvidas com crescimento celular, como TGF e CD31. De fato, o tratamento com Ácido Glutâmico modulou a proliferação e diferenciação de Queratinócitos como também a expressão de células BrDu positivas.

Palavras-chave: Imunomodulação. Ácido glutâmico. Pele. 